\title{
Organization and Management of Digital Education in Uzbekistan During the COVID-19 Pandemic
}

\author{
Zulfiya Khamdamovna Inoyatova ${ }^{1}$, Guzal Makhkambaevna Ergasheva1, Gulchekhra Tashpulatovna \\ Islamova $^{1 *}$, Anna Genadievna Saidova ${ }^{1}$ \\ ${ }^{1}$ Tashkent State Pedagogical University, Uzbekistan. Tashkent City, Uzbekstan. \\ *Islomovagula@gmail.com
}

\begin{abstract}
The outbreak of coronavirus infection has affected billions of people around the planet. According to the latest data from Worldometers, as of July 26, 2020, the total number of infected is in the region of 16,357,563 people, deaths are 6\% - 650,738 of the number of infected. On March 11, 2020, the World Health Organization officially declared the coronavirus a pandemic. In 188 countries of the world, decisions were made to temporarily close educational institutions in order to contain the spread of the virus. The scale of the measures taken is unprecedented and, according to UNESCO, affected $90 \%$ of the world's students. Experts believe that such measures will slow the rate of spread of the virus, as children can potentially be hidden carriers of the virus. This article examines various ways to organize the educational process in the context of the COVID-19 pandemic in Uzbekistan. Also, the article analyzes the issues of the educational crisis, solutions to this crisis and the experiences of foreign countries on this issue.
\end{abstract}

Keywords

COVID-19, educational crisis, online education, educational package.

Article Received: 18 October 2020, Revised: 3 November 2020, Accepted: 24 December 2020

\section{Introduction}

Like many countries, Uzbekistan also had to close schools across the country to prevent the spread of the virus. This decision was made on March 15, the same day when the first case of coronavirus infection was recorded in the country. Two days later, the Ministry of Public Education (MOE) announced an unprecedented government decision to launch a distance learning program for the country's 6.1 million schoolchildren during quarantine.

The main problem during the school closure period is the difficulty in ensuring equal access to education, especially in the context of limited resources. It is incorrect to assume that all students have access to distance learning resources and the same opportunities to do so during the period when schools are in quarantine. In fact, such a crisis has a negative impact mainly on socially vulnerable students, many of whom live in remote areas and do not have access to electronic devices (computers, tablets, phones) and the Internet.
In Uzbekistan, the population is still experiencing difficulties with access to the global network. About a third of the population is still not provided with Internet access. At the same time, almost $50 \%$ of the country's citizens live in rural areas (World Bank, 2018). As of March 2020, the country ranks 133rd in the world for mobile internet speed and 95th for fixed broadband speeds.

For these reasons, the INE recognizes that online learning will not be able to provide equal access to educational resources for all students in the country. However, with $100 \%$ coverage of the territory of Uzbekistan with digital television, the use of television broadcasting is the only possible option for providing mass distance learning.

Although there are still some unresolved issues, the response of the Ministry of Education to the crisis and the establishment of distance learning was prompt. So, in just a few days, 350 video lessons were prepared, and from March 30 they began broadcasting on several state TV channels. Lessons are available in Uzbek and Russian with 
sign language translation. In parallel, these videos are posted on the social networks of the Ministry of Education and Science, including on the video platforms YouTube and Mover.uz, as well as on the website kundalik.com, a platform for managing the educational process (Meliboeva N., Harry A. Patrinos, Janssen Teixeira, 2020).

\section{Review}

\section{Pandemic education crisis}

All over the world, educational institutions were closed, regardless of country, time and culture. This raises the question of looking after children, whose parents carry out work activities. The simplest childcare solution may no longer work in light of the risks associated with the spread of the virus.

As a result of the termination of the activities of universities, their hostels are closed. Consequently, all over the world we see problems with housing for students who, for one reason or another, cannot return home. Part-time students, in addition, have problems with work and food, since most of the enterprises in which they worked are also closed due to quarantine rules.

Another important problem is ensuring the continuity of education. Most countries in the world are switching to distance learning in the form of radio broadcasting, online platforms and broadcasting lessons via television.

The coronavirus (COVID-19) pandemic has a long-term negative impact on education, the quality of human capital and socio-economic development in Central Asian countries, where students, children and young people make up almost half of the population. The crisis threatens the future incomes of the younger generation. The rate of functional illiteracy among adolescents is projected to increase, that is, an increasing number of students are unable to use their reading, writing and math skills to participate effectively in society, according to the World Bank (World Bank Conference Edition, 2020).

Prior to the pandemic, education in Central Asia already faced a number of challenges, in particular, difficulties in eliminating educational poverty, providing equal opportunities to vulnerable students and promoting inclusiveness. On average, students from Central Asian countries lagged behind their peers in Europe by a year and a half. Many students in the region have already performed poorly in functional literacy according to the results of the international assessment program

Of particular concern is the growing inequality, or gap, in learning between students from families with different income levels. This is due to a number of factors, including differences in the availability of distance learning and teaching materials for teachers and students, as well as in the support of teachers and the family's contribution to home teaching. According to PISA data, in Kazakhstan, children from the poorest families lag behind their peers in education by one year, and in the Kyrgyz Republic - by two and a half years.

The COVID-19 pandemic has exacerbated learning challenges, as school closures will further negatively impact the most vulnerable, including students from disadvantaged families, remote areas, minorities, and people with special needs.

\section{Is online education a must?}

In this situation, the demand for online education is growing all over the world, at first such education was on a short-term basis, but recently a regulatory document was issued confirming the continuation of online education for the next year. Many online platforms now provide free educational courses for those interested around the world. For example, companies such as Scholastic, Udemy, and Coursera provide distance learning for young people and have a simple interface. And more responsible organizations like Yeoju Technical Institute in Tashkent (my employer) paid for online courses and made such training free for all employees and students. These initiatives are also supported by international organizations, in particular UNESCO (UNESCO). Education for All is the watchword of the nonprofit organization Khan Academy, which also offers free courses. First of all, the main trump 
card of online education is its flexibility, that is, students can combine their studies with other activities.

This turn of events is likely to be a turning point in the development of the education system. With the increasing frequency of virtual education experiments under the threat of a pandemic, consumers can get a new hybrid education product. We can confidently assume that even after the end of the pandemic, online teaching will continue to be in great demand, since from an economic point of view, it is a "non-competitive good", i.e. an additional consumer does not make it less accessible to others. Consequently, the gaining momentum of online learning technologies can put competitive pressure on the education sector in the form of a "bending of the education cost curve", i.e. lower prices, and in terms of increased productivity.

\section{Educational package}

In order to determine which types of distance learning and in which countries are most widely used during the pandemic, we used the recently formed database of the Center for Global Development. This data includes the latest information on school closures for primary and secondary education (K-12, generally considered kindergarten through grade 12) for 218 countries and regions around the world, which are ranked by the World Bank in terms of profitability and regions. By examining this data, it is possible to identify the types of distance learning by country with different levels of profitability for K-12.

Distance learning options for primary and secondary education vary widely across income groups. For example, $75 \%$ of high-income countries offer online learning platforms (YouTube video tutorials, resource websites, online classes, etc.). Education through television and online platforms is almost equally popular among lower- and upper-middle-income countries. Of particular note, only $40 \%$ of lowincome countries have organized any type of distance learning. It is very significant that, despite the prevalence of other types of education, about $10 \%$ of all countries deliver printed teaching materials home to their students.

In addition, the types of distance learning used vary across regions of the world. For example, more than $50 \%$ of countries from all regions except Sub-Saharan Africa provide online education for their students. It can also be noted that the transmission of lessons through television is very popular among South Asian countries (75\%).

Now it is difficult to determine the further vector of events, how the coronavirus will affect this or that industry, including the education system. However, the global closure of educational institutions is likely to disrupt the traditional educational process, and distance education acts as a key solution to this problem.

Analysis of the current situation around the world shows that due to the consequences of COVID-19, low-income countries will be the most affected, as they will practically not be able to ensure the continuity of education. Also geographically, African countries will face challenges in providing any type of distance learning. After the end of the pandemic, educational institutions in these countries will need resources to rebuild learning and other losses. The question of the formation of these resources and their directing to especially affected students remains open.

\section{Prompt response of Uzbekistan}

A day later, after the detection of the first case of coronavirus infection in Uzbekistan, by the decision of the Special Republican Commission, preschool, secondary and higher educational institutions were closed for a three-week quarantine from March 16, 2020. Such an immediate response, especially in the very early stages of the spread of the virus, is highly effective and highly recommended by international experts. At that moment, about 80 thousand students from other regions of the country studied in Tashkent. To return to their place of permanent residence, they were provided with $50 \%$ discounts on transport services (Davletov, 2020). 
The closure of educational institutions in the country means that about 8.4 million students, most of whom (about 6 million people) are students from general education schools, will be at home during the quarantine. In these conditions, the main task of the government in the field of education has become the continuous provision of the educational process. In this regard, various types of distance learning were organized throughout the republic. In particular, the Ministry of Public Education has prepared broadcasting lessons for all classes in accordance with the curriculum. There is an official telegram channel UZEDU of the Ministry of Public Education and a channel on the YouTube video hosting, where the schedule of TV lessons is published and directly recordings of these lessons for all classes.

At an equally rapid pace, the Ministry of Higher and Secondary Specialized Education began to form online resources on higher education standards and launched the EDUUZ telegram channel, which also publishes information on the latest developments in the field of education and posts materials for self-education. At the same time, the process of formation of more than 3500 electronic textbooks in various disciplines continues, which are posted on the website "Innovation Kutubkhona".

To mitigate the negative consequences of the spread of coronavirus, two packages of social and economic measures were approved by the decree of the President of the Republic of Uzbekistan. A wide range of measures taken are directly related to issues related to education. Parents of pupils of preschool educational organizations and primary school students of general education schools are provided with annual leave, including for those who have worked less than 6 months. It is prohibited to terminate an employment contract with an employee who is a parent (person, substitute, guardian, guardian) of a child infected with coronavirus infection or quarantined on the initiative of the employer, as well as under 14 years of age. For persons caring for children under the age of 14 , temporary disability benefits are paid in the amount of 100 percent of the average wage.

In addition, according to the decree, timely payment of wages to employees of preschool, general secondary, secondary specialized and higher educational institutions, sports and cultural institutions financed from the State budget and suspended their activities is guaranteed.

The measures taken in this direction have solved two main issues related to the closure of educational institutions. The first is to look after the students of preschool and general education institutions, the second is their financial support during quarantine.

\section{Digital challenge of Uzbek education}

Despite the fact that various types of distance education are being implemented in the republic, a high-quality educational process requires interactivity between teacher and students, which is possible only through online classes. In most cases, users face a number of common problems differences in the availability of communication channels, lack of equipment and software, poor quality of telecommunication services.

According to the latest data from the Ministry for the Development of Information Technologies and Communications for March 2020, in the overall ranking of Internet speed among 176 countries, the Republic of Uzbekistan ranks 96th, and in terms of mobile Internet speed - 133rd. In addition, according to the information portal Datareportal, in 2020 only $55 \%$ of the population (18.34 million people) use the Internet (Digital 2020: Uzbekistan).

These numbers indirectly indicate that Internet speed has become an issue for most students. My students, who live in the provinces, sat on the rooftops of their houses at all during online classes. Moreover, even those who have access to the Internet are not always able to pay its cost. But, the government of Uzbekistan has decided to defer payments for the Internet and mobile communications up to 2 months during quarantine. Also, the deferral applies to utility bills. So, according to the analysis of experts from 
Picodi.com, conducted in December 2019, Uzbekistan took 11th place among 62 countries in terms of the average cost of the Internet for 100 megabits per second ( $\mathrm{m} / \mathrm{s})$. For comparison: in Uzbekistan, the cost of $100 \mathrm{~m} / \mathrm{s}$ is $\$ 51$, in neighboring Kazakhstan - \$ 11 (Digital 2020: Kazakhstan), and in Kyrgyzstan - \$ 34 (Digital 2020: Kyrgyzstan).

The measures taken by the government regarding online education during the pandemic can take education in the republic to a new level, while additional measures should be taken to improve the quality of the Internet services provided. The needs for technological modernization should be determined, the issues of organizing retraining and additional training for teachers should be considered.

\section{Online education catalyst}

Uzbekistan has already taken effective measures to prevent the consequences of COVID-19, such as the timely suspension of the activities of educational institutions, the continuous broadcast of lessons on TV and the formation of more online resources.

Quality learning requires interactivity. This is, first of all, a dialogue between a student and a teacher, which is currently only possible with online lessons. Therefore, at the first stage, it is necessary to establish monitoring of 6 million students of secondary schools for the availability of affordable and high-quality Internet. Based on the results of the study, methods should be developed to provide these students with equipment for Internet access. Such a solution can be considered a long-term investment in human capital, since even after the end of the pandemic, students will have the opportunity to improve their skills using advanced technologies.

Another key problem is training teachers in new digital products and new infrastructure. An online platform Kundalik.uz was formed with the aim of tracking and assessing the knowledge of students in secondary schools, i.e. students could submit completed assignments for review to teachers and receive appropriate grades and comments in an electronic journal. Due to the innovation of this platform, the parties still experience some difficulties in using it.

In a pandemic, accelerated digitalization can be a test of the strength of teachers, educational institutions and the national education system.

There is a paradigm shift in the entire education system, and we can say with confidence that it will not be the same. Society is getting used to online learning, and the crisis is a catalyst that has accelerated the development of online education.

How is the online learning process going, what are the nuances and difficulties?

After the case of the first coronavirus patient was detected in Tashkent, schools and universities in Uzbekistan switched to distance learning. A teacher at one of the capital's educational institutions, Zarina Shamiyeva, told how the first two weeks of remote lessons went.

\section{Novelty with costs}

According to the teacher, since the spring break, which begins at the end of March, was not very long, the news about distance learning was initially received by schoolchildren and their parents very well.

"It was like something new. But it should also be noted that many of the parents were in shock. They did not know what to do, how to be. In the first week, the guys did the tasks that we, the teachers, threw in the parent group on Telegram. Students completed assignments and sent photo reports, and we checked them, "she says.

But by the beginning of the second week, many parents started asking the teacher to teach online lessons. According to Shamiyeva, in recent days, some students who worked intensively at first have slowed down. However, there were those who did not really work during this entire period. The teacher explains this by the fact that the parents of the schoolchildren are a little tired of the load, because each lesson is now explained by the parent, not the teacher (Rakhmatova, 2020).

\section{Triple load}

The teacher does not deny that remote work is not as easy as it seems at first glance. The advantages 
are that for teachers it was like mastering new electronic capabilities, they learned to use gadgets more confidently, learned something new, but also felt a triple load. For example, when checking homework.

"Now you need to copy, check, and then send every work. That is, checking the homework of each student turned into a triple work. My eyes started to water," Shamiyeva complains (Rakhmatova, 2020).

Another difficulty is the limited ability to monitor students if it is not possible to conduct an online lesson. For example, if earlier, when the teacher came to the classroom, announcing the results of homework, he interviewed those present in front and time was saved, then in distance learning you have to work with each child individually.

With the presentation of material on the recognition of a teacher, television is very helpful. So, the channel "Dunyo builab" prepares lessons on natural history and biology, and "Bolajon" broadcasts a program for the first and second grades.

Also on the website of the Ministry of Public Education, a list of online resources has been published where you can find ready-made lessons of teachers, honored teachers of the republic from all regions.

\section{How to motivate parents and students}

Zarina Shamieva is sure that the main thing in this process is to interest the students themselves and their parents.

"Much depends on the worldview of the child's parents, on their attitude to his education in general. We have parents who generally gave up on raising their child, they do not get in touch at all. Can you imagine their son or daughter does not study for two weeks, does not do his homework, does not do his homework, and the teacher cannot contact him? We have a lot of such students. There are more than 40 people in the class, and only 10 parents work, "the teacher says bitterly (Rakhmatova, 2020).
But everyone understands that the main thing in such a situation is health, and you can wait out temporary measures.

The parents' workload has also increased - they are in a panic, they get confused a lot, because now they have to explain to the child in all subjects. In such a situation, the positive motivation of the student is half the battle.

"It is important to interest the child so that the educational process does not become an occasion for him to protest and internal resistance." explains the teacher.

At the same time, in the context of online learning, it makes no sense to overload the child. Moreover, in urban environments. The schoolboy is already within four walls, he cannot go outside now, and this also makes its mark.

According to Shamiyeva, there is certainly an effect of distance learning, although it cannot be compared with a full-fledged educational process.

"This is not to say that it is completely useless. Humanity communicates through gadgets, children gain knowledge - this is already a blessing. In addition, people have learned to use their gadgets correctly, to filter information, "says the source.

Distance learning during quarantine provides a good opportunity not to stop in your intellectual, spiritual development, even staying at home constantly.

\section{Distance education is not for everyone}

Unfortunately, not all parents can yet afford remote learning for their children.

"So far, this is problematic, because so far only those students whose parents are provided with laptops or home Internet can use these resources," Shamiyeva clarified.

The teacher sees the only way out in the human relationship. For example, ask wealthy parents during an online lesson to give a neighbor's child the opportunity to participate in the process.

Now Uztelecom is preparing a special platform for online conferences. When it works, teachers will be able to conduct full-fledged online classes for students (Rakhmatova, 2020). 
Teachers who work in private schools: what will happen to them during the quarantine?

The pandemic has forced most states to reconsider their budgetary policies and pay attention to the priority costs in the distribution of funds, especially at the beginning. First of all, in countries like Uzbekistan, where the standard of living is not so high, this is a very important and urgent task.

After the period of the pandemic, it will be necessary not only to assess the damage caused, both in economic and social aspects, but also to create an effective system for the next years, to try to save the most important industries. When it comes to relative advantages, one should expect that there will be restrictions on spending on entertainment, sports, various social events that do not play a big role in the country's economic life.

However, certain areas are considered relatively necessary. Such industries can partially take on the burden that the state will bear in the future. But for this, we should try to preserve them today, in the near future.

For example, general secondary education is compulsory for everyone. This area was completely taken over by the state, which allocates a significant part of the budgetary funds in this direction. In fact, in the conditions of Uzbekistan, it is a little wrong that the state fully provides education - firstly, as mentioned above, our well-being is not so great, and secondly, even in the most developed states, the costs in the education system are partially borne by private schools. More precisely, parents educate their children in private schools at their own expense, and thus facilitate the task of the state.

It is easy to see that this area has also begun to develop in Uzbekistan in recent years. In the capital, regional centers, cities, private secondary schools began to operate. In such private schools, which provide better education and infrastructure in comparison with budget schools, the monthly cost of education ranges from 200-300 thousand sums to several million. Thus, parents, based on their financial capabilities, by sending a child to one or another private school, reduce the burden of budget schools.

That is, the father, having given money for paid education, teaches the child at his own expense. In fact, one should not forget that public schools are also not free educational institutions, the budget for their financing consists of the funds of the same parents, say, from the taxes paid. That is, it turns out that the father paid money to the state through taxes to educate his child. But nevertheless, for a better education, he pays another fee and sends the child to a private school. This system has many advantages: first, the state is partially freed from the need to create a sufficient number of places and conditions for the education of children. Secondly, due to the fact that teachers' salaries are formed precisely from parental money, it is no longer necessary to pay them salaries from the budget. Third, an additional economy is being created, private schools, instead of taking money for education from the state, on the contrary, pay the state money in the form of taxes. Fourth, additional competition will be created for budget schools, various administrative barriers will be removed, and the quality of education will increase. There are several more such examples, in a word, private education can certainly be very effective in our country, both from an economic and social point of view.

Now let's take a look at the current situation in a pandemic. Although the Ministry of Public Education has closed schools and only an online system is in place, teachers are paid salaries. Of course, there are no complaints about teachers who go out of their way to carry out their duties online despite the inconvenience.

However, private schools, funded not from the budget, but from parental funds, faced great difficulties. Naturally, when a child stays at home and learns only on TV or through online lessons, parents are unwilling to pay private schools. Because now the conditions of private and public schools are equal - why pay money? This is understandable. 
In turn, the heads of private schools were also left without income, and, of course, they are not able to pay out of their own pockets a monthly salary of several tens or hundreds of millions. Someone may have organized some kind of minimum wage or material assistance to protect their staff, but not everyone did that. And how long will it be? They can also be understood.

In addition, you can understand and teachers of private schools. They were left without pay until at least September. We can certainly wish them to work, appealing to their dedication and dedication to education, but we cannot demand that. And it's just unfair to expect them to teach online lessons for free, give assignments, grade students, keep records, write notes. Needless to say, the quality of education will also decline.

With all this in mind, you can imagine the situation in which private school teachers are now. Such a situation can not only create problems in the current period of a pandemic, but also entail a lag of several steps in a system that can be very effective in the future.

Think, because teachers of private schools now do not feel socially protected, unlike teachers in budget schools, and who knows, maybe next year they will start looking for another job. To retain teachers, private school owners will have to offer them additional conditions, and this area may not be profitable from an economic point of view. And if the number of private schools decreases and they do not develop, then all the burdens of education will again fall on the shoulders of the state. Needless to say, budgetary spending will go up.

Therefore, the state today should pay attention to private schools and, if possible, try to preserve this area.

It is true that when the roof is leaking, all other problems seem to be secondary. After all, there are already many areas where direct assistance is required. However, as it was said, it is very important to preserve the areas that will serve as a support for the state in the future. For example, such monopoly spheres as mechanical engineering, aviation and railways will undoubtedly be able to stand on their own feet there is both demand and supply. However, in the field of private education, the demand may disappear, and perhaps in a few years we will part with this effective area.

When I asked the head of one of the private schools, which had been operating for several years, for comment, he said the following:

"It's very difficult for us now. When we gave the initiative to the parents' discretion, different opinions arose. Someone understood everything correctly and agreed to partially pay. Some did not want to pay and said that they could help teachers. There were also those who said: before that you made a good profit, and if you live off this profit for several months, nothing will happen. In such a situation, it is impossible to please everyone, for this reason we asked the parents not to interfere and forbade paying both to us and separately to the teachers. Now we are at our own expense, albeit not in the same amount as before, but we are trying to pay teachers the minimum wage of one and a half million. Naturally, both we and teachers are losing income. "

\section{The present situation is unfair for students in the private education system and their parents.}

If we put the extraneous factors aside, and consider the fact that schools are funded by taxes, these funds are collected from everyone. Namely, the parents of children enrolled in both public and private schools finance public schools by paying taxes. In other words, parents of the second category have already paid money to the state for the education of their child. And in private schools, money is spent on additional quality. Thus, certain expenses of the state are reimbursed. Asking parents to continue paying for private school in today's online environment is simply illogical.

You should also pay attention to the following fact. One should not think that only the children of wealthy entrepreneurs study in private schools with good conditions. If we look at the centers, then, of course, we get such an impression, but 
there are also private schools with a small fee, which usually pay rent (Aslanov, 2020).

Parents are forced to send their children to such schools, not for the sake of unnecessary luxury, but to get a normal education. It's no secret that even among budget schools, the difference in quality is striking (Islamova, 2020). If you remember, there were problems with the territorial distribution of the best schools, and the Minister of Public Education Sherzod Shermatov had to intervene in the situation. Hence, one should consider the natural emergence of private schools as opposed to low-quality free education.

Now that private schools have no income, why should their students suffer? Why should a teacher teaching these children be left unpaid?

If now the state does not pay them a two-threemonth salary, and tomorrow this will lead to the loss of a certain part of private schools, then the state will still have to deal with these students. Then it will be necessary to pay additional salaries to teachers for several years, rather than several months. And if you think not only from a social, but also from a rational point of view, the preservation of private schools can benefit the state.

In my opinion, the state in these conditions should treat private schools in the same way as budget ones, and at least reimburse teachers' salaries from the state budget (according to the usual scale for school teachers) during the quarantine period.

\section{Students during quarantine: what about scholarships?}

During the quarantine period, students will be paid a scholarship in accordance with the established procedure. The only change in the payment method is that those who receive it in cash will receive a scholarship on the student's plastic card.

Scholarships to students of all universities in the country were paid for March this year. At the same time, it was found that there were delays in the payment of scholarships due to non-payment of contract fees, academic debt, failure to comply with an order or the issuance of a bank card.
In most cases, students' late fulfillment of the terms of the payment agreement was the main reason for delays in the payment of scholarships and the opening of bank cards.

The ministry is currently compiling information on students not paying scholarships in the country. Them:

unpaid cash scholarships are mailed to the student's place of residence or distributed through a list through the district bank branches;

payment is made by bank plastic cards, new cards are opened for students who have not opened plastic cards, and are delivered through the regional branch of a banking institution.

The Ministry of Higher and Secondary Special Education officially announces that those who do not comply with the terms of payment and contract during the quarantine period at universities will not be excluded from the ranks of students.

In addition, all students will be paid full fees in due course, depending on the form of study and the type of payment of their choice.

\section{How distance education works in Uzbekistan during quarantine}

The country is under quarantine, which means that not only state educational institutions, but also private educational projects go online.

For example, Timur Azamatov, co-founder and head of the RoboKidz robotics school and the Nest business school for children, said that he was transferring Nest to the Zoom video conferencing service.

The entrepreneur noted that the effectiveness of online education is several times lower: there are many distractions, lack of focus, and high selfmotivation is needed. In addition, the internet speed, while better than before, is still insufficient. Among the advantages, Azamatov noted the opportunity to gather large groups and work from home. However, with distance learning, there is no way to distribute the construction kits needed at RoboKidz to children. To keep this business going, the entrepreneur intends to focus on building a franchise: 
- I have been collecting material for this for a long time, now I will accelerate, we will cut costs and look for an online format for training.

Botir Arifdzhanov, founder of Paynet, LeBazar, Khan Academy O'zbek (a project to localize the international educational platform Khan Academy), noted that almost all schools, especially private ones, from the first day of quarantine began to use online technologies for distance learning - Google Classroom, Yandex. Textbook. To create at least some kind of virtual environment for communication with children, some teachers create groups in Telegram.

- There will definitely be a huge interest in online education, there is already a multiple increase in content consumption at Khan Academy O'zbek. If earlier the number of active users was 2-3 thousand, over the last week this figure reached 7 thousand and this is without active promotion from us and the Ministry of Public Education, - he said.

The entrepreneur believes that the education system should be rebuilt to adapt to new realities, but there are pitfalls that can slow down implementation.

- Online education is divided into two parts: supplier and consumer, and there are problems on both sides. $90 \%$ of teaching is conducted in the state language, there is a huge lack of content. We do not have enough good specialists who can provide high-quality author's content in the Uzbek language. It is to be expected that a tremendous amount of work will be done to localize existing content in the first place.

According to the businessman, a consensus should be reached on some linguistic norms of Uzbek, since a huge amount of vocabulary comes into the language and does not go through systematization. This was what the entrepreneur's team faced when they started translating the Khan Academy platform. Affected by the lack of qualified translators who could translate from English.

It also requires the preparation of teachers: they must understand and control the online process, and all this must reach the end consumer - the student.

- We have a stereotype that children go to school reluctantly, and it will not be easy to get a child to study online, at least at the initial stages. This will require a lot of attention from the parents, who must explain to the child and be involved in the learning process.

In addition to behavioral problems, there are fundamental infrastructure problems. Internet in the country is not the cheapest and coverage in rural areas is poor. UCell and UMS have started to work towards supporting online education and there is a chance that other companies will join them.

- It is quite difficult in our realities to implement online projects: you immediately run into the absence of an accessible Internet, its coverage in other settlements. In this case, Tas-IX does not play a big role, first of all it is necessary to reach out to end users. Cellular operators or Uzbektelecom should be involved in this case, Arifjanov said.

In addition to the lack of the Internet, the lack of computers affects the students. The businessman cited the experience of Georgia as an example, where the state gives every first grader a laptop.

Talking about Telegram as a possible tool for distance education, Botir noted that it has many limitations. Learning requires interactivity, feedback from the student is needed so that he has the opportunity to test his knowledge. Some tasks can be added to the messenger, but from the user's point of view, this is difficult.

Arifdzhanov added that the quarantine will give an impetus to entrepreneurs to develop online education.

- There are several language centers that are trying to gather their students online, and for this they will need ready-made solutions, or they will create their own. So, they will generate demand for the active development of this area. Of course, after the end of the pandemic, interest will subside a little, but I think the boost that will be gained during the outbreak will be a very good impetus. 
Vyacheslav Kan, founder and director of the MyWay Career Guidance Center, Torg.uz (OLX), noted that many problems will have to be faced when introducing distance learning.

- There is also a poor quality of the Internet or its absence, as well as computers. There is no experience in organizing and conducting online lessons, especially among teachers, and programs are also needed to meet the needs of all students. But all these issues are solvable - demand and the current situation will sooner or later lead to their solution, - he commented.

However, there are other problems associated with mentality, attitudes towards education on the part of parents, children and society. Learning outside of school presupposes strong motivation, especially among the children themselves. But traditional schooling is built on discipline, grades, and curriculum and does not structure the process in a way that engages and motivates children. When a student is at home, if he is not interested in development, it will be difficult to force him to study, as it was done before.

"Parents still trust offline learning more, considering desks, live teacher control as necessary attributes of the educational process," said the entrepreneur.

He noted that it is difficult to give advice in a crisis, such a situation in the country and in the world for the first time, but here there is also an opportunity for development.

- I must admit that now everyone can find any information by himself. The teacher needs to transform into a teacher: instead of teaching, helping to learn. In many progressive schools in the world, their main goal is to interest the child. Then he himself will research, find information, study everything related to this topic. This is not easy to do, since we were all trained in a different system.

According to Kahn, a different solution is needed for the education of the remote format to be of high quality. There is no need to force all the children to sit at the same time at the monitors and listen to the teacher, when you can give some interesting topic in the form of a project, unite children into teams, add competitive moments, suggest where and how you can find information. If you change the approach to education in general, then the appropriate tools and methods will be found.

- If now the Ministry of Education and Science tries to introduce a single standard for all schools, a single program for all, then finding a solution will not be so easy, because we are talking about creating a new infrastructure. It is difficult to find a program that can simultaneously serve hundreds of thousands of connections; you need powerful servers with good access to the Internet. Implementing all of this quickly is not an easy task. It is much more effective today to allow schools and teachers to be flexible and inventive, to find ways and methods that would allow children to learn and develop.

The entrepreneur emphasized that the result is important, not the process. You can make a list of possible solutions, recommendations, instructions, organize seminars and workshops for teachers on working online. It will be necessary to create conditions for teachers: provide the necessary equipment, provide the Internet.

He also added that it is hoped that the surge in online learning will not be a one-off, and that this area will continue to develop.

- Until now, many people have preferred traditional education and may not have trusted online education. But, as usual, in order to understand something, you must first try it. Quarantine will lead many to become familiar with online education, and the field itself will improve rapidly. There will surely be those who decide to try it further. I think that the current situation will contribute to the development of various startups in the field of online training, services for holding online conferences and webinars, demand always gives rise to supply (Ten, 2020). 


\section{Conclusion}

It's as if you are forced to do the impossible. As a teacher in the field of online education and creditmodular learning, since 2014, we have tried to introduce the basics of distance and online learning into the education system of Uzbekistan. The very fact of organizing digital school education through TV, Internet and radio within a week during quarantine, and $100 \%$ transition to a credit-modular system of higher and postgraduate education within two weeks, confirmed the fact that, if necessary, the Uzbek people will literally do EVERYTHING for their children and citizens.

\section{References}

[1] Meliboeva N., Harry A. Patrinos, Janssen Teixeira. (2020). Prompt provision of the learning process during the period of school closure for quarantine in Uzbekistan. Blogs Worldbank. 27.04.2020 Available

to: https://blogs.worldbank.org/ru/europeandc entralasia/uzbekistan-timely-responselearning-during-school-closures

[2] Davletov F. (2020). Global Impact of COVID-19 on the Education System. Review.uz. 23.04.2020. Available to: https://review.uz/ru/post/globalnoevliyanie-covid19-na-sistemu-obrazovaniya

[3] Islamova G.T. (2020). The Formation of Spiritual and Moral Qualities Among Junior School Children. Journal of Advanced Research in Dynamical and Control Systems, 12(6s): 650-659. DOI: 10.5373/JARDCS/V12SP6/SP20201 076

[4] Simon Kemp (2020). Digital 2020: Kazakhstan. Available to: https://datareportal.com/reports/digital2020-kazakhstan

[5] Simon Kemp (2020). Digital 2020: Kyrgyzstan. Available to: https://datareportal.com/reports/digital2020-kyrgyzstan
[6] Simon Kemp (2020). Digital 2020: Uzbekistan. Available to: https://datareportal.com/reports/digital2020-uzbekistan?rq=Uzbekistan

[7] Simulating the Potential Impacts of COVID-19 School Closures On Schooling and Learning Outcomes: A Set of Global Estimates. June 2020, World Bank Conference Edition. Available to: http://pubdocs.worldbank.org/en/7980615 92482682799/covid-and-educationJune17-r6.pdf

[8] Rakhmatova D. (2020). Learning Network: how Uzbekistan is switching to online lessons. Sputniknews.uz. 27.03.2020 Available to: https://uz.sputniknews.ru/society/2020032 7/13790488/Uchene---Set-kakUzbekistan-perekhodit-na-onlaynuroki.html

[9] Aslanov, Kakhramon. (2020) Teachers who don't burden the state budget: who will save them during the quarantine period? Kun.uz. 20.05.2020. Available to: https://kun.uz/ru/news/2020/05/20/uchitely a-ne-obremenyayushchiye-gosbudjet-ktospaset-ix-v-period-karantina

[10] Ten, Alexander. (2020). How distance education works in Uzbekistan during quarantine. Forbes.uz. 25.03.2020. Available to: https://forbes.uz/process/science/granit_na uki_chto_jdet_distantsionnoe_obrazovanie _v_uzbekistane_vo_vremya_koronavirusa/ 